\section{Anesthesiologists' Approach to the Treatment of Catheter Related Bladder Discomfort: A Survey Study}

\author{
Anesteziyologların Idrar Sondasına Bağlı Mesane \\ Rahatsızlığının Tedavisine Yaklaşımı: \\ Bir Anket Çalışması
}

\begin{abstract}
Objective: Urinary catheterization causes catheter related bladder discomfort (CRBD) in the early postoperative period following all surgeries. CRBD mostly develops after urological interventions and has two independent predictors: Male gender and urinary catheters $\geq 18 \mathrm{~F}$. We aimed to investigate the awareness of Anesthesiology and Reanimation specialists to CRBD and its treatment.

Methods: After ethics committee approval, a questionnaire with informed consent of 20 multiplechoice and open-ended questions was transferred to docs.google.com. and Turkish Society of Anesthesiology and Reanimation Specialists were contacted for contribution.

Results: 144 anesthesiologists, 26-66 years old (39.5 \pm 8.02 years), $54.5 \%$ males, $45.5 \%$ females, $66.4 \%$ with a teaching position and $55.5 \%$ with $>10$ years of experience participated. $54.4 \%$ reported encountering $>1$ CRBD per week and mostly following urology (70.9\%), obstetrics and gynecology $(52.5 \%)$ and general surgery $(51.1 \%)$ cases. The frequency and severity (66\% and $69.5 \%$ ) of CRBD was reported higher in male patients. $94.4 \%$ agreed that CRBD should be treated. $37.8 \%$ believed the surgeon should manage CRBD, 60.1\% believed it should be planned together. All male participants stated treatment was necessary $(p=0.008)$. Participants chose preemptive $(19.9 \%, n=28)$, symptomatic $(80.1 \%, n=113)$ or both $(4.3 \%, n=6)$ treatments. The choices for preemptive and symptomatic treatment were similar; non-steroidal anti-inflammatory drugs $(70.8 \%, 59 \%)$, paracetamol $(43.4 \%, 50.7 \%)$ and tramadol $(18.9 \%, 21.6 \%)$. Participants' knowledge on factors effecting CRBD was lacking.

Conclusion: Anesthesiologists do not utilize preemptive and effective treatment for CRBD; one thirds of them do not consider it their responsibility. Anesthesiologists should be aware of CRBD and participate in the treatment using multimodal approaches.
\end{abstract}

Keywords: Anesthesia, urinary catheterization, urinary bladder, pain, perioperative care, survey öz

Amaç: Üriner kateterizasyon, tüm ameliyatları takiben erken postoperatif dönemde idrar sondasına bağlı mesane rahatsızlığına (iSBMR) neden olur. iSBMR çoğunlukla ürolojik girişimlerden sonra gelişir ve iki bağımsız prediktöre sahiptir: Erkek cinsiyet ve $18 \mathrm{~F}$ üriner kateter. Bu çalışmada Anesteziyoloji ve Reanimasyon uzmanlarının iSBMR ve tedavisi konusundaki farkındalıklarını araştırmayı amaçladık.

Yöntem: Etik kurul onayından sonra, 20 çoktan seçmeli ve açık uçlu sorudan oluşan bilgilendirilmiş onam içeren bir anket docs.google.com'a aktarıldı. Türk Anesteziyoloji ve Reanimasyon Derneği ile katkıları için iletişime geçildi.

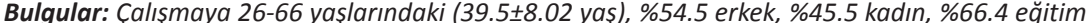
kadrosunda ve \%55.5> 10 yıl deneyimli 144 anestezist katılmıştır. Katılımcıların \%54.4'ü haftada 1'den fazla iSBMR ile karşılaştığını ve bunların çoğunlukla üroloji (\%70.9), obstetrik ve jinekoloji (\%52.5) ve genel cerrahi (\%51.1) vakalarını takip ettiğini belirtti. Erkek hastalarda iSBMR'nin sıklığı ve şiddeti (\%66 ve \%69.5) daha yüksek bildirildi. Anesteziyoloji ve Reanimasyon uzmanlarının \%94.4'ü iSBMR'nin tedavi edilmesi gerektiğini onaylarken. \%37.8'i cerrahın iSBMR'yi yönetmesi gerektiğine, \%60.1'i ise cerrahla birlikte planlanması gerektiğine inanıyordu. Tüm erkek katılımcllar tedavinin gerekli olduğunu belirttiler ( $p=0.008)$. Katılımcılar tedavide önleyici $(\% 19.9, n=28)$, semptomatik (\%80.1, $n=113$ ) yaklașımları veya her ikisini $(\% 4.3, n=6)$ seçtiler. Tercih edilen önleyici ve semptomatik tedavi seçenekleri benzerdi; non-steroid anti-inflamatuar ilaçlar (\%70.8, \%59), parasetamol (\%43.4, \%50.7) ve tramadol (\%18.9, \%21.6). Katılımciların isBMR'yi etkileyen faktörler hakkındaki bilgileri eksikti.

Sonuç: Anesteziyoloji ve Reanimasyon uzmanları, iSBMR için önleyici ve etkili tedavileri kullanmamakta ve üçte biri bu rahatsızlığı kendi sorumlulukları olarak görmemektedir. Anesteziyologlar, isBMR'nin farkında olmalı ve multimodal yaklaşımlar kullanarak tedavisine katılmalıdır.

Anahtar kelimeler: Anestezi, idrar kateterizasyonu, mesane, ağrı, perioperatif bakım, anket

(C) Telif hakkı Anestezi ve Reanimasyon Uzmanları Derneği. Logos Tıp Yayıncııık tarafindan yayınlanmaktadır. Bu dergide yayınlanan bütün makaleler Creative Commons 4.0 Uluslararası Lisansı ile lisanslanmıştr.

(c) Copyright Anesthesiology and Reanimation Specialists' Society. This journal published by Logos Medical Publishing. Licenced by Creative Commons Attribution 4.0 International (CC)
Received/Geliş: 20 March 2021 Accepted/Kabul: 20 May 2021 Publication date: 16 July 2021

Cite as: Köksoy ÜC, Kazak Bengisun Z, Yılmaz H, Kazbek BK, Tüzüner F. Anesthesiologists' approach to the treatment of catheter related bladder discomfort: A survey study. JARSS 2021;29(3):165-71.

Ülkü Ceren Köksoy Ufuk Üniversitesi Tıp Fakültesi, Anesteziyoloji ve Reanimasyon Anabilim Dalı,

Ankara, Türkiye cerenkoksoy@gmail.com ORCID: 0000-0003-3815-9220

Z. Kazak Bengisun 0000-0002-0731-2969

H. Yılmaz 0000-0001-9978-6370

B.K. Kazbek 0000-0002-1230-7814

F. Tüzüner 0000-0003-3432-4399 Ufuk Üniversitesi Tıp Fakültesi, Anesteziyoloji ve Reanimasyon Anabilim Dall, Ankara, Türkiye 


\section{INTRODUCTION}

Urinary catheterization often causes urinary catheter related bladder discomfort (CRBD) in the early postoperative period following all surgeries, mainly urological surgery. CRBD which is frequent in patients with a urinary catheter in the postoperative period, mostly develops as a result of urological interventions, most commonly transurethral resection of bladder tumors ${ }^{(1)}$. The common utilization of urinary catheters within the past years has led to an increase in the incidence of CRBD (47-90\%) and has been rising despite the numerous treatment alternatives that have proven to be effective ${ }^{(2-4)}$.

The hallmark of CRBD is increased frequency of urination and a feeling of urgency in addition to findings of overactive bladder. Its findings resemble an overactive bladder; a feeling of discomfort in the suprapubic region, a sensation of burning, increased frequency of urination, urge incontinence and a feeling of urgency ${ }^{(2,5)}$. CRBD has two independent predictors: Male gender and size of urinary catheters $\geq 18 \mathrm{~F}^{(6)}$. Although it can affect both males and females, the incidence and severity of CRBD is higher in males which is often attributed to the longer length and the sigmoid curvature of the male urethra $(4,7)$.

We aimed to investigate the approach and awareness of the Anesthesiology and Reanimation specialists to CRBD and its treatment in this survey study.

\section{MATERIAL and METHODS}

The study used a questionnaire that had multiple choice and open-ended answers aimed to evaluate Turkish Anesthesiology and Reanimation specialists' approaches to the treatment of "urinary catheter related bladder discomfort". A pilot study was conducted using 19 questions to which 20 participants responded and necessary changes were made based on the feedback. Ethics committee approval was obtained (No: 02022017-9). The final version of the questionnaire consisted of 20 questions. One question was open ended, 11 questions required one answer while more than one choice could be selected for the remaining 8 questions. Four questions were about demographic data, 11 were about the awareness of CRBD and the remaining five were about its treatment. An informed consent section was added to the beginning of the questionnaire. The answers were transferred to docs.google.com (Link: https://docs.google.com/forms/d/e/1FAIpQLSe Tc6EmITBkimL_mM82Sigib62MaDPy4uW1Z8LUtvAQnWGJVQ/viewform?c=0\&w=1). Turkish Society of Anesthesiology and Reanimation Specialists were contacted for the distribution of the questionnaire. The call for participants was made online on June $16^{\text {th }}$ 2017 and were sent via e-mail to participants. The questionnaire remained accessible between June $16^{\text {th }}$-August $17^{\text {th }}, 2017$ and 144 specia-lists responded.

Data was obtained using Google Forms and Spreadsheets while statistical analyses were performed using SPSSC for Windows, Version 21.0 Armonk, NY, IBM Corp. Descriptive statistics were used for average, standard deviation, percentage and frequency, independent groups t-test was used for intergroup comparisons while chi-squared test was used for the intergroup comparison of categorical variables.

\section{RESULTS}

One hundred and forty-four Anesthesiology and Reanimation specialists ( $54.5 \%$ males, $45.5 \%$ females) aged between 26-66 with an average of 39.5 \pm 8.02 years has participated in the study. The comparison

Table I. Demographic data

\begin{tabular}{lcc}
\hline Age (mean \pm SD) ( $n=138)$ & $39.5 \pm 8$ & \\
& $\%$ & Year \\
\hline Gender (Female/Male) ( $n=143)$ & $54.5 \% / 45.5 \%$ & $78 / 65$ \\
Years of Experience in the Anesthesiology & & \\
and Reanimation Department ( $n=143)$ & & \\
$1-<5$ years & $18.9 \%$ & 27 \\
$5-<10$ years & $25.9 \%$ & 37 \\
$10-<15$ years & $27.3 \%$ & 39 \\
$15-<20$ years & $9.1 \%$ & 13 \\
$20-<25$ years & $9.4 \%$ & 15 \\
$25-<30$ years & $5.7 \%$ & 8 \\
$>30$ years & $2.8 \%$ & 4 \\
Institution ( $n=143)$ & & \\
University Hospital & $32 \%$ & 46 \\
Health Ministry Training and Research & $29 \%$ & 41 \\
$\quad$ Hospital & & \\
State Hospital & $17 \%$ & 24 \\
Foundation University Hospital & $6 \%$ & 8 \\
Private Hospital & $15 \%$ & 22 \\
Other & $1 \%$ & 2 \\
& & \\
\hline
\end{tabular}

SD: Standard deviation, $n$ : Number, \%: Percent 
of the distribution of ages, with t-test, of the female and male participants whose median values for age were $39.5 \pm 8.71$ and $39.5 \pm 7.15 \mathrm{yr}$ respectively, revealed that the ages of the two sexes were similar with no statistical significance ( $p=0.989$ ). The $27.8 \%$ of the specialists who participated had more than 15 years of experience while $27.1 \%$ had $10-14$ and $27.7 \%$ had $5-9$ years. A total of $55.5 \%$ of the participants had more than 10 years of experience (Table I). Thirty-seven percent of them were employed in a university $(32.2 \%$ government universities, $5.6 \%$ foundation universities), $28.7 \%$ in education and research hospitals, $16.8 \%$ in government hospitals and $15.4 \%$ in private hospitals. The rema-ining $1.4 \%$ responded as "other". Overall, $66.4 \%$ of the participants held a teaching position (Table I).

The incidence of CRBD was reported as $55.2 \%$ in all cases with a urinary catheter and as $34.6 \%$ in cases longer than 3 hours. A higher incidence of CRBD was observed in urology (70.9\%), obstetrics and gynecology $(52.5 \%)$ and general surgery $(51.1 \%)$ cases. $54.4 \%$ of the participants reported that they encountered at least one case of CRBD per week. The frequency and severity (66\% and $69.5 \%$, respectively) of CRBD was reported as higher in male patients. CRBD was more frequent following general anesthesia $(87.9 \%)$ compared to spinal $(22.9 \%)$ and epidural (7.1\%) anesthesia (Table II).

Even though the ratio of participants who believed that CRBD should be treated to increase patient comfort was $94.4 \%, 60.1 \%$ of the Anesthesiology and Reanimation specialists believed that the treatment should be planned with the surgeon. Furthermore $37.8 \%$ believed that the surgeon alone should manage CRBD while only $2.1 \%$ believed that the anesthesiologist alone should manage the treatment. All (100\%) of the male participants stated that treatment was necessary while $89.6 \%$ of the female participants shared this opinion and the difference was statistically significant $(p=0.008)$ (Table III).

When asked about the cases where they deem a urinary catheter necessary, the participants responded as cases with a duration of more than 3 hours (86.5\%), cases with a high risk of kidney injury (79.4\%), cases where fluid resuscitation is carried out $(73 \%)$ and cases where blood transfusion is car-
Table II. Factors effecting the frequency and severity of catheter related bladder discomfort

\begin{tabular}{|c|c|c|}
\hline & $\%$ & $\mathbf{n}$ \\
\hline \multicolumn{3}{|l|}{ The Relationship with Surgical Factors $(n=138)$} \\
\hline The type of surgery & $50 \%$ & 69 \\
\hline The invasiveness of surgery & $47.8 \%$ & 66 \\
\hline Abnormal urine output during surgery & $34.8 \%$ & 48 \\
\hline Intraoperative trauma & $58.7 \%$ & 81 \\
\hline Other & $5.1 \%$ & 7 \\
\hline \multicolumn{3}{|l|}{ The Relationship with Surgical Branches ( $n=141)$} \\
\hline Urology & $70.9 \%$ & 100 \\
\hline Gynecology and obstetrics & $52.5 \%$ & 74 \\
\hline General surgery & $51.1 \%$ & 72 \\
\hline Plastic surgery & $13.5 \%$ & 19 \\
\hline Orthopedics & $36.2 \%$ & 51 \\
\hline Ear-Nose-Throat surgery & $8.5 \%$ & 12 \\
\hline Neurosurgery & $27.7 \%$ & 39 \\
\hline Cardiovascular surgery & $18.4 \%$ & 26 \\
\hline Ophthalmology & $3.5 \%$ & 5 \\
\hline Pediatric surgery & $6.4 \%$ & 9 \\
\hline Thoracic surgery & $18.4 \%$ & 26 \\
\hline \multirow{2}{*}{\multicolumn{3}{|c|}{$\begin{array}{l}\text { The Relationship Between Surgical Procedure } \\
\text { Length and Catheter Related Bladder Discomfort } \\
\text { Frequency }(n=143)\end{array}$}} \\
\hline & & \\
\hline In all cases with a urinary catheter, no matter the & $55 \%$ & 79 \\
\hline duration & כ5\% & 19 \\
\hline In cases lasting shorter than 1 hour & $1.4 \%$ & 2 \\
\hline In cases lasting $1-2$ hours & $4.2 \%$ & 6 \\
\hline In cases lasting 2-3 hours & $12.6 \%$ & 18 \\
\hline In cases lasting more than 3 hours & $36.4 \%$ & 52 \\
\hline \multirow{2}{*}{\multicolumn{3}{|c|}{$\begin{array}{l}\text { The Relationship Between Anesthesia Type and } \\
\text { Catheter Related Bladder Discomfort }(n=140)\end{array}$}} \\
\hline & & \\
\hline General anesthesia & $87.8 \%$ & 123 \\
\hline Epidural anesthesia & $7.1 \%$ & 10 \\
\hline Spinal anesthesia & $22.9 \%$ & 32 \\
\hline Sedoanalgesia & $12.9 \%$ & 18 \\
\hline Peripheric nerve block & $5 \%$ & 7 \\
\hline \multirow{2}{*}{\multicolumn{3}{|c|}{$\begin{array}{l}\text { Relationship Between Factors About the Urinary } \\
\text { Catheter and Catheter Related Bladder Discomfort } \\
(n=141)\end{array}$}} \\
\hline & & \\
\hline The type of urinary catheter & $45.4 \%$ & 64 \\
\hline The size of urinary catheter & $69.5 \%$ & 98 \\
\hline The duration of urinary catheter & $61 \%$ & 86 \\
\hline Lubricant used for insertion of the urinary catheter & $41.8 \%$ & 59 \\
\hline Trauma during the insertion of the urinary catheter & $86.5 \%$ & 122 \\
\hline \multicolumn{3}{|c|}{$\begin{array}{l}\text { Frequency of Catheter Related Bladder Discomfort } \\
(n=139)\end{array}$} \\
\hline In every patient with urinary catheter & $16.5 \%$ & 23 \\
\hline Once a day & $7.9 \%$ & 11 \\
\hline 2-5 times a day & $17.3 \%$ & 24 \\
\hline More than 5 times a day & $3.6 \%$ & 5 \\
\hline Once a week & $20.1 \%$ & 28 \\
\hline 2-5 times a week & $26.6 \%$ & 37 \\
\hline More than 5 times a week & $7.9 \%$ & 11 \\
\hline \multicolumn{3}{|l|}{$\begin{array}{l}\text { The Relationship Between Patient Gender and Fre- } \\
\text { quency of Catheter Related Bladder Discomfort } \\
(n=141)\end{array}$} \\
\hline Male patients & $66 \%$ & 93 \\
\hline Female patients & $13.5 \%$ & 19 \\
\hline Same in both genders & $20.6 \%$ & 29 \\
\hline The Relationship Between Patient Gender and & & \\
\hline \multicolumn{3}{|l|}{$\begin{array}{l}\text { Severity of Catheter Related Bladder Discomfort } \\
(n=141)\end{array}$} \\
\hline Male patients & $69.5 \%$ & 98 \\
\hline Female patients & $12.8 \%$ & 18 \\
\hline Same in both genders & $17.7 \%$ & 25 \\
\hline
\end{tabular}

$\%:$ Percent, $n:$ Number 
ried out (63.8\%) (Table II).

For the treatment of CRBD the participants chose preemptive $(19.9 \%, \mathrm{n}=28)$, symptomatic $(80.1 \%$, $\mathrm{n}=113)$ or both $(4.3 \%, \mathrm{n}=6)$ treatments. The most frequent agents for preemptive treatment were nonsteroidal anti-inflammatory drugs (NSAID) (70.8\%), paracetamol (43.4\%) and tramadol (18.9\%). The drug choices for symptomatic treatment were similar but with different frequencies; NSAID (59\%), paracetamol $(50.7 \%)$ and tramadol $(21.6 \%)$. No participant used peripheral nerve blocks for the pre-

Table III. The treatment approaches of anesthesiologists for catheter related bladder discomfort

\begin{tabular}{|c|c|c|c|c|c|}
\hline & & & & \multicolumn{2}{|l|}{$\%$} \\
\hline \multicolumn{6}{|c|}{$\begin{array}{l}\text { The Ratio of Anesthesiologists Who Believe That } \\
\text { Catheter Related Bladder Discomfort Should Be }\end{array}$} \\
\hline \multicolumn{4}{|c|}{ Treated $(n=142)$} & 94.4 & 134 \\
\hline \multicolumn{4}{|l|}{ Female } & 89.6 & 69 \\
\hline \multirow{2}{*}{\multicolumn{4}{|c|}{$\begin{array}{l}\text { Male } \\
\text { Who Should Be Responsible for The Treatment? } \\
\text { ( } n=143)\end{array}$}} & $100^{*}$ & 65 \\
\hline & & & & & \\
\hline \multicolumn{4}{|c|}{ Anesthesiologist } & 2.1 & 3 \\
\hline \multicolumn{4}{|l|}{ Surgeon } & 37.8 & 54 \\
\hline \multicolumn{4}{|l|}{ Both } & 60.1 & 86 \\
\hline \multicolumn{6}{|c|}{$\begin{array}{l}\text { The Circumstances Where the Anesthesiologist } \\
\text { Requests A Urinary Catheter }(n=141)\end{array}$} \\
\hline \multicolumn{4}{|c|}{ In cases lasting shorter than 1 hour } & 0 & 0 \\
\hline \multicolumn{4}{|c|}{ In cases lasting 1-3 hour long } & 6.4 & 9 \\
\hline \multicolumn{4}{|c|}{ In cases lasting longer than 3 hours } & 86.5 & 122 \\
\hline \multicolumn{4}{|c|}{ In cases with fluid resuscitation } & 73 & 103 \\
\hline \multicolumn{4}{|c|}{ In cases with blood or blood product replacement } & 63.8 & 90 \\
\hline \multicolumn{4}{|c|}{ In cases which have a risk of renal failure } & 79.4 & 112 \\
\hline \multirow{2}{*}{\multicolumn{6}{|c|}{$\begin{array}{l}\text { Other } \\
\text { Anesthesiologists' Choice of Treatment ( } n=141)\end{array}$}} \\
\hline & & & & & \\
\hline \multirow{3}{*}{\multicolumn{4}{|c|}{$\begin{array}{l}\text { Preemptive treatment } \\
\text { Symptomatic treatment } \\
\text { The Ratio of Peripheric Nerve Block Use Among } \\
\text { Anesthesiologists for The Treatment Of Catheter } \\
\text { Related Bladder Discomfort ( } n=143)\end{array}$}} & 19.9 & 28 \\
\hline & & & & 84.4 & 119 \\
\hline & & & & & \\
\hline \multicolumn{4}{|c|}{ Preemptive } & 0 & 0 \\
\hline \multicolumn{4}{|l|}{ Symptomatic } & 0 & 0 \\
\hline $\begin{array}{l}\text { The Drug Preferences } \\
\text { of Anesthesiologists }\end{array}$ & $\begin{array}{l}\text { Preemptive } \\
\%\end{array}$ & $\begin{array}{c}(n=106) \\
n\end{array}$ & $\begin{array}{l}\text { Symptomati } \\
\%\end{array}$ & & $\begin{array}{l}(n=134) \\
n\end{array}$ \\
\hline $\begin{array}{l}\text { Non-steroidal } \\
\text { anti-inflammatory } \\
\text { drugs }\end{array}$ & 70.8 & 75 & 59 & & 79 \\
\hline Paracetamol & 43.4 & 46 & 50.7 & & 68 \\
\hline Scopolamine & 4.7 & 5 & 14.2 & & 19 \\
\hline Tramadol & 18.9 & 20 & 21.6 & & 29 \\
\hline Meperidine & 9.4 & 10 & 17.9 & & 24 \\
\hline Gabapentin & 1.9 & 2 & 3 & & 4 \\
\hline Ketamine & 0 & 0 & 0.7 & & 1 \\
\hline Opioids & 14.2 & 15 & 15.7 & & 21 \\
\hline Dexmedetomidine & 1.9 & 2 & 4.5 & & 6 \\
\hline Other & 16 & 17 & 16.4 & & 22 \\
\hline
\end{tabular}

${ }^{*} p=0.008$, statistically significant, Fishers Exact Test $\%$ : Percent, n: Number emptive or symptomatic treatment of CRBD (Table III).

When the participants were asked which features of the urinary catheter, they thought caused CRBD, they stated traumatic insertion during catheterization (86.5\%) as the most important prognostic factor which was followed by the size of the catheter (69.5\%), duration of catheterization (61\%), type of catheter $(45.4 \%)$ and utilization of a lubricant during catheterization (41.8\%) (Table II).

The participants' answers revealed surgery related trauma (58.7\%) as the most important factor associated with surgery which was followed by type of surgery $(50 \%)$, invasiveness of the surgery $(47.8 \%)$ and abnormal urine output (34.8\%) as risk factors associated with CRBD (Table II).

\section{DISCUSSION}

Urinary catheter related bladder discomfort is defined as a feeling of urgency or a discomfort in the suprapubic region and is characterized by frequent and urgent urination ${ }^{(6)}$. $15-25 \%$ of all the hospitalized patients have a urinary catheter which is more common in patients who undergo surgery ${ }^{(4)}$ and the incidence of CRBD is $47-90 \%$. In this study $54.6 \%$ of the participants stated that they observe CRBD at least once a week while $55.2 \%$ reported CRBD in every case with a urinary catheter and $36.4 \%$ observed CRBD in surgeries that last for more than 3 hours.

The participants expressed that the frequency and severity of CRBD (66\% and $69.5 \%$, respectively) is higher in male patients. Parallel to our results, Lim et al. ${ }^{(7)}$ reported more CRBD in male patients compared to female patients in the first 24 postoperative hours with no significant difference in surgical pain severity among sexes which was explained by the longer urethra in men. Similarly, Bach et al. (3) explained the increased severity and frequency of CRBD in men by the longer urethra which has a sigmoid curvature.

Even though the majority of the participants believe that CRBD should be treated in order to increase patient satisfaction, only approximately two thirds of the participating anesthesiology and reanimation 
specialists believe that treatment should be planned together with the surgeon, $37.8 \%$ believe that the surgeon alone should plan the treatment and $2.1 \%$ believe that they were responsible for the treatment. Based on these results, it is safe to assume that the anesthesiologists do not want to actively participate in the treatment of this complication which is reported to be the second most common cause of discomfort after pain ${ }^{(3,6)}$ and it causes agitation during recovery and postoperative delirium ${ }^{(8-10)}$. Furthermore, when left untreated CRBD can cause increased stress, postoperative agitation and pain while having a negative impact on patient satisfaction and quality of life consequently delaying recovery ${ }^{(11,12)}$. Dehiscence of the surgical wound, bleeding, hemodynamic instability and increased severity of coronary artery diseases have also been reported (1). As such, in our opinion, the anesthesiology and reanimation specialists in our country need to have an increased awareness of the early postoperative CRBD and actively participate in its treatment in order to increase the postoperative quality of care.

Another important well-known risk factor for CRBD is the diameter of the catheter ${ }^{(6)}$. As the adult female urethra is $4 \mathrm{~cm}$ and the adult male urethra is $18-20 \mathrm{~cm}$ long, with both of them having a $6 \mathrm{~mm}$ diameter, a $16 \mathrm{~F}$ catheter can be used safely due to its $5.3 \mathrm{~mm}$ diameter. On the other hand, $>18 \mathrm{~F}$ catheters have been shown to be an independent risk factor for CRBD ${ }^{(6,7)}$. Only $45.4 \%$ of the participants in our study reported the type of catheter was a risk factor which pointed to a low level of awareness among anesthesiology and reanimation specialists concerning the size of the urinary catheter.

Urinary catheter related bladder discomfort is most commonly observed in urological surgeries and its frequency is highest in transurethral bladder resections followed by percutaneous nephrolithotomies and non-urological surgery ${ }^{(1)}$. Other surgeries with a high incidence of CRBD are gynecologic and obstetric surgeries ${ }^{(7)}$. Parallel to the literature, the participants declared that the surgeries they observed which had a higher incidence of CRBD were urology, obstetrics and gynecology and general surgery in our study. Li et al. ${ }^{(13)}$ have suggested that laparotomies and a history of urinary catheterization within 3 months could be predictors of CRBD. Lim et al. (7) stated that although pain associated with urinary catheter, obstetrics and gynecology surgery and age $<50$ years were risk factors while body mass index, duration of surgery and postoperative pain in the surgical field were not predictors of CRBD. On the other hand, Song et al. (2) have identified age $>50$, laparoscopic uterine surgery and lack of additional analgesics as independent risk factors for moderate and severe CRBD.

The participants of this study reported that the most important surgical factor contributing to CRBD was surgical trauma, followed by the type of surgery, invasiveness of surgery and abnormal urine output during surgery. Based on these results, it can be said that anesthesiologists are not fully aware of the pathophysiology of CRBD.

The pathophysiology of CRBD is similar to overactive bladder ${ }^{(14)}$ which is characterized by involuntary contractions of the bladder via muscarinic receptors. The urinary catheter irritates the bladder mucosa and endothelium through muscarinic receptors, which in turn causes involuntary contraction of the bladder in CRBD ${ }^{(15)}$. Numerous studies have shown the effectiveness of anticholinergics such as tolterodine, oxybutynin ${ }^{(3,4)}$, muscarinic receptor antagonists such as butyl scopolamine, solifenacin ${ }^{(1)}$, glycopyrrolate ${ }^{(16)}$, in addition to gabapentin, pregabalin, ketamine (17), tramadol ${ }^{(18)}$, morphine, fentanyl and paracetamol in a dose dependent manner ${ }^{(3)}$. The efficacy of alpha-2 agonists such as dexmedetomidine, amicasin, peripheral nerve blocks, caudal block, dorsal penile block, lidocaine-prilocaine cream in addition to desflurane, sevoflurane and propofol have been investigated ${ }^{(19)}$. Oral gabapentin has been shown to reduce the incidence for six hours postoperatively ${ }^{(20)}$ while tolterodine has been more effective in reducing the severity of CRBD ${ }^{(19)}$. Muscarinic antagonists can cause dryness in the mouth, flushing and loss of visual acuity; ketamine, gabapentin and paracetamol can cause sedation and tramadol can cause sedation, respiratory depression. Tolterodine is a suitable agent for preoperative use in CRBD due to its low side effect profile ${ }^{(1)}$.

The participants chose preemptive (19.9\%, $n=28)$, symptomatic $(80.1 \%, n=113)$ and both $(4.3 \%, n=6)$ treatments. Nonsteroidal anti-inflammatory drugs 
were most frequently chosen for both preemptive and symptomatic treatment. Peripheral nerve blocks were not chosen by any of the participants for preemptive or symptomatic treatment. Based on the treatment options and the responses of the anesthesiologists, we can assume that CRBD is not effectively treated.

The main limitation of this study is the inclusion of only anesthesiology and reanimation specialists while neglecting to survey any surgeons. Other limitations were the lack of questions about the age of patients which mostly suffered CRBD and the severity of it in patients.

In conclusion, we observed that more than one thirds of the anesthesiology and reanimation specialists do not consider CRBD as their responsibility and do not actively participate in its treatment. The participants did not utilize preemptive treatment or choose antimuscarinic agents which are proven to be effective in treatment. In light of our findings, we believe that anesthesiologists should increase their awareness, particularly in surgeries performed under neuraxial anesthesia where CRBD might be overlooked, be educated about multimodal treatment approaches and actively participate in postoperative treatment of CRBD.

Ethics Committee Approval: Ufuk University Faculty of Medicine Non-Invasive Clinical Research Evaluation Committee Ethics Committee Approval was obtained (02022017-9).

\section{Conflict of Interest: None}

Funding: None

Informed Consent: Questionary study

\section{REFERENCES}

1. Bai Y, Wang X, Li X, et al. Management of catheter-related bladder discomfort in patients who underwent elective surgery. J Endourol. 2015;29:640-9. https://doi.org/10.1089/end.2014.0670

2. Li SY, Song LP, Ma YS, Lin XM. Predictors of catheterrelated bladder discomfort after gynaecological surgery. BMC Anesthesiol. 2020;20:97. https://doi.org/10.1186/s12871-020-01018-6

3. Bach H, Kaasby K, Sørensen A, Løfqvist S, Laursen BS. Incidence and severity of catheter-related bladder discomfort among nonurological adult patients in a postanesthesia care unit. J Perianesth Nurs. 2020;35:2933. https://doi.org/10.1016/j.jopan.2019.06.013

4. Hu B, Li C, Pan M, et al. Strategies for the prevention of catheter-related bladder discomfort: A PRISMAcompliant systematic review and meta-analysis of randomized controlled trials. Medicine (Baltimore). 2016;95:e4859. https://doi.org/10.1097/MD.0000000000004859

5. Ergenoglu P, Akin S, Yalcin Cok O, et al. Effect of intraoperative paracetamol on catheter-related bladder discomfort: a prospective, randomized, double-blind study. Curr Ther Res Clin Exp. 2012;73:186-94. https://doi.org/10.1016/j.curtheres.2012.08.001

6. Binhas M, Motamed C, Hawajri N, Yiou R, Marty J. Predictors of catheter-related bladder discomfort in the post-anaesthesia care unit. Ann Fr Anesth Reanim. 2011;30:122-5. https://doi.org/10.1016/j.annfar.2010.12.009

7. Lim N, Yoon H. Factors predicting catheter-related bladder discomfort in surgical patients. J Perianesth Nurs. 2017;32:400-8. https://doi.org/10.1016/j.jopan.2016.03.012

8. Zegerman A, Ezri T, Weinbroum AA. Postoperative discomfort (other than pain) - a neglected feature of postanesthesia patient care. J Clin Monit Comput. 2008;22:279-84. https://doi.org/10.1007/s10877-008-9130-3

9. Yu D, Chai W, Sun X, Yao L. Emergence agitation in adults: risk factors in 2,000 patients. Can J Anaesth. 2010;57:843-8. https://doi.org/10.1007/s12630-010-9338-9

10. Tsang LF, Yeung CH, Tse CC, et al. Developing a predictive tool for post-operative delirium in orthopaedic settings in Hong Kong. Int J Orthop Trauma Nurs. 2012;16:147-59. https://doi.org/10.1016/j.ijotn.2012.03.005

11. Ryu JH, Hwang JW, Lee JW, et al. Efficacy of butylscopolamine for the treatment of catheter-related bladder discomfort: a prospective, randomized, placebocontrolled, double-blind study. $\mathrm{Br} J$ Anaesth. 2013;111:932-7. https://doi.org/10.1093/bja/aet249

12. Agarwal A, Raza M, Singhal V, Dhiraaj S, Kapoor R, Srivastava A. The efficacy of tolterodine for prevention of catheter-related bladder discomfort: a prospective, randomized, placebo-controlled, double-blind study. Anesth Analg. 2005;101:1065-7. https://doi.org/10.1213/01.ane.0000167775.46192.e9

13. Li C, Liu Z, Yang F. Predictors of catheter-related bladder discomfort after urological surgery. J Huazhong Univ Sci Technolog Med Sci. 2014;34:559-62. https://doi.org/10.1007/s11596-014-1315-z

14. Anderson KE. Pharmacology of lower urinary tract smooth muscles and penile erectile tissues. Pharmacol Rev 1993;45:253-308.

15. Singh TK, Sahu S, Agarwal A, Gupta D, Mishra P. Dexmedetomidine for prevention of early postoperative catheter-related bladder discomfort in voluntary kidney donors: Prospective, randomized, double-blind, placebo-controlled trial. J Anaesthesiol Clin Pharmacol. 2018;34:211-5.

16. Kim H, Lim S, Seo H, Park H. Effect of glycopyrrolate versus atropine coadministered with neostigmine for reversal of rocuronium on postoperative catheter-related bladder discomfort in patients undergoing tran- 
surethral resection of bladder tumor: a prospective randomized study. J Anesth. 2015;29:831-5.

https://doi.org/10.1007/s00540-015-2064-2

17. Shariat Moharari R, Lajevardi M, Khajavi M, Najafi A, Shariat Moharari G, Etezadi F. Effects of intra-operative ketamine administration on postoperative catheterrelated bladder discomfort: a double-blind clinical trial. Pain Pract. 2014;14:146-50.

https://doi.org/10.1111/papr.12055

18. Agarwal A, Yadav G, Gupta D, Singh PK, Singh U. Evaluation of intra-operative tramadol for prevention of catheter-related bladder discomfort: a prospective, randomized, double-blind study. $\mathrm{Br} J$ Anaesth. 2008;101:506-10. https://doi.org/10.1093/bja/aen217

19. Hur M, Park SK, Yoon HK, et al. Comparative effectiveness of interventions for managing postoperative catheter-related bladder discomfort: a systematic review and network meta-analysis. J Anesth. 2019;33:197-208.

https://doi.org/10.1007/s00540-018-2597-2

20. Bala I, Bharti N, Chaubey V, Mandal A. Efficacy of gabapentin for prevention of postoperative catheter-related bladder discomfort in patients undergoing transurethral resection of bladder tumor. Urology. 2012;79:853-7.

https://doi.org/10.1016/j.urology.2011.11.050 